\title{
Early development and life cycle of Contracaecum multipapillatum s.l. from a brown pelican Pelecanus occidentalis in the Gulf of California, Mexico
}

\author{
Isabel Valles-Vega ${ }^{1,3, *}$, Dolores Molina-Fernández ${ }^{2, *}$, Rocío Benítez ${ }^{2}$, \\ Sergio Hernández-Trujillo ${ }^{1}$, Francisco Javier Adroher ${ }^{2, * *}$ \\ ${ }^{1}$ Departamento de Plancton y Ecología Marina, Centro Interdisciplinario de Ciencias Marinas, Instituto Politécnico Nacional, \\ Av. IPN s/n, Col. Playa Santa Rita, 23096-La Paz, Baja California Sur, México \\ ${ }^{2}$ Departamento de Parasitología, Facultad de Farmacia, Universidad de Granada, 18071-Granada, Spain \\ ${ }^{3}$ Present address: CIBNOR, Centro de Investigaciones Biológicas del Noroeste, S.C., \\ Km. 1 Carretera a San Juan de La Costa ‘El Comitán', 23097-La Paz, Baja California Sur, México
}

\begin{abstract}
The initial developmental stages of Contracaecum multipapillatum (von Drasche, 1882) Lucker, 1941 sensu lato were studied using eggs obtained from the uteri of female nematodes (genetically identified) found in a brown pelican Pelecanus occidentalis from Bahía de La Paz (Gulf of California, Mexico). Optical microscopy revealed a smooth or slightly rough surface to the eggs. Egg dimensions were approximately $53 \times 43 \mu \mathrm{m}$, although after the larvae had developed inside, egg size increased to $66 \times 55 \mu \mathrm{m}$. Hatching and survival of the larvae were greater at $15^{\circ} \mathrm{C}$ than at $24^{\circ} \mathrm{C}$, and increased salinity resulted in a slight increase in hatching but seemed to reduce survival at $24^{\circ} \mathrm{C}$, but not at $15^{\circ} \mathrm{C}$. The recently hatched larvae measured $261 \times 16 \mu \mathrm{m}$ within their sheath. When placed in culture medium, the larvae grew within their sheath, and a small percentage $(\sim 2 \%)$ exsheathed completely $(314 \times 19 \mu \mathrm{m})$. The larvae continued to grow and develop once they had exsheathed, attaining mean dimensions of $333 \times 22 \mu \mathrm{m}$. Although they did not moult during culture, optical microscopy revealed a morphology typical of third-stage larvae. Finally, the genetic identity between the larval parasites collected from mullet Mugil curema and adult female parasites collected from the brown pelican suggests a life cycle of $C$. multipapillatum in which the mullet are involved as intermediate/paratenic hosts and the brown pelicans as final hosts in the geographical area of Bahía de La Paz.
\end{abstract}

KEY WORDS: Contracaecum multipapillatum $\cdot$ Nematoda $\cdot$ Anisakidae $\cdot$ Fish parasite $\cdot$ Genetic identification · Development $\cdot$ Aquatic life cycle $\cdot$ Mullet $\cdot$ Brown pelican $\cdot$ Gulf of California

\section{INTRODUCTION}

Nematodes of the genus Contracaecum (Ascaridoidea: Anisakidae) parasitize fish-eating birds and marine mammals as their definitive hosts, while the larvae use planktonic crustaceans and fish as intermediate/paratenic hosts (Anderson 2000). If accidentally ingested, the third larval stage (L3) found in fish may infect humans, causing anisakidosis (contra-

\footnotetext{
* These 2 authors contributed equally to this work

${ }^{* *}$ Corresponding author: fadroher@ugr.es
}

caecosis) and possibly allergic reactions. In Germany, Schaum \& Müller (1967) described the first human case of contracaecosis in the medical literature. Im et al. (1995) studied 107 cases of gastric anisakiasis in Cheju-do (South Korea), and after examining the collected larvae of the patients, found 1 larva of Contracaecum type A (= C. osculatum s.l.). Ishikura et al. (1996) later described 2 new cases in Hokkaido (Japan). All cases described to date have

(C) The authors 2017. Open Access under Creative Commons by Attribution Licence. Use, distribution and reproduction are unrestricted. Authors and original publication must be credited. 
been caused by C. osculatum s.l. Recently, Shamsi \& Butcher (2011) reported the first anisakidosis case in Australia caused by a larva of Contracaecum sp. Although no allergic reactions related to the ingestion of larvae of the genus Contracaecum in food have been described, these may well occur as they have been reported in other genera of anisakids, such as Anisakis (e.g. Daschner et al. 2012) and Hysterothylacium (Valero et al. 2003).

C. multipapillatum (von Drasche, 1882) Lucker, 1941 (sensu lato) consists of a complex of sibling species which parasitize fish-eating birds, principally of the family Pelicanidae (Mattiucci et al. 2010). The life cycle of these parasites is complex and has yet to be clarified. According to Huizinga (1967), the second larval stage (L2, with the L1 sheath) hatches from the egg into the water and is ingested by a copepod. It then frees itself from the sheath in the intestine of the copepod before passing to the coelom, where it grows without moulting. When the infected copepod is ingested by the first fish host (small planktivorous fish), L2 reaches the abdominal cavity, grows and moults to L3. When this fish is ingested by a larger, piscivorous fish, L3 grows in the abdominal cavity but does not moult. When this fish is ingested by a suitable fish-eating bird host, L3 lodges in the proventriculus where it grows, moulting twice to the adult stage. After fertilization of the female by the male, the eggs are passed in faeces from the final host to the water. The L2 larvae then develop inside the eggs, finally hatching, after which the larvae are free in the water until they are ingested by a new intermediate host.

Deardorff \& Overstreet (1980) attempted experimental oral infection of chickens, ducks and rats with L3 of C. multipapillatum obtained from fish, without success, although a few larvae placed in the abdominal cavity of rats developed to the adult stage. At a later date, Vidal-Martínez et al. (1994) again tried to infect animals, this time including cats in the experiment. While the chickens, ducks and rats were not infected orally when using L4 collected from the Mayan cichlid Cichlasoma urophthalmus, the cats were not only infected, but the larvae also developed to the adult stage, at least 3 of these being found firmly attached to the intestine where they caused haemorrhaging similar to that associated with small ulcers. In addition, Barros et al. (2004) infected rabbits experimentally with C. multipapillatum L3 from fish, which caused gastric lesions. All of these authors warned of the potential risks to human health resulting from the accidental ingestion of this parasite.

C. multipapillatum s.l. has been found both in commercially important fish of the mullet family Mugilidae (as L3) and in brown pelicans Pelecanus occidentalis (as L3, L4 and adults) from Mexico and other regions of America (Deardorff \& Overstreet 1980, Iglesias et al. 1998, 2011, Valles-Ríos et al. 2000, Valles-Vega 2011, 2014). Furthermore, in these areas, where mullets form part of the diet of these birds, infections have been found in brown pelicans as young as 2 wk (Humphrey et al. 1978).

The present study describes the early developmental stages of C. multipapillatum s.l. and the first attempt at their in vitro culture in nutritive media in order to further our knowledge of the biology of this parasite, to determine its life cycle and to describe eggs and larvae using optical microscopy.

\section{MATERIALS AND METHODS}

\section{Host and parasite collection}

A total of 353 adult nematodes were obtained from the digestive tract of male adult brown pelican from Bahía de La Paz, Baja California Sur, Mexico (Fig. 1). Six females of Contracaecum multipapillatum s.l., identified at CICIMAR de La Paz (Mexico) using the morphological characteristics of males that accompanied them (Lucker 1941, Yamaguti 1961), were sent

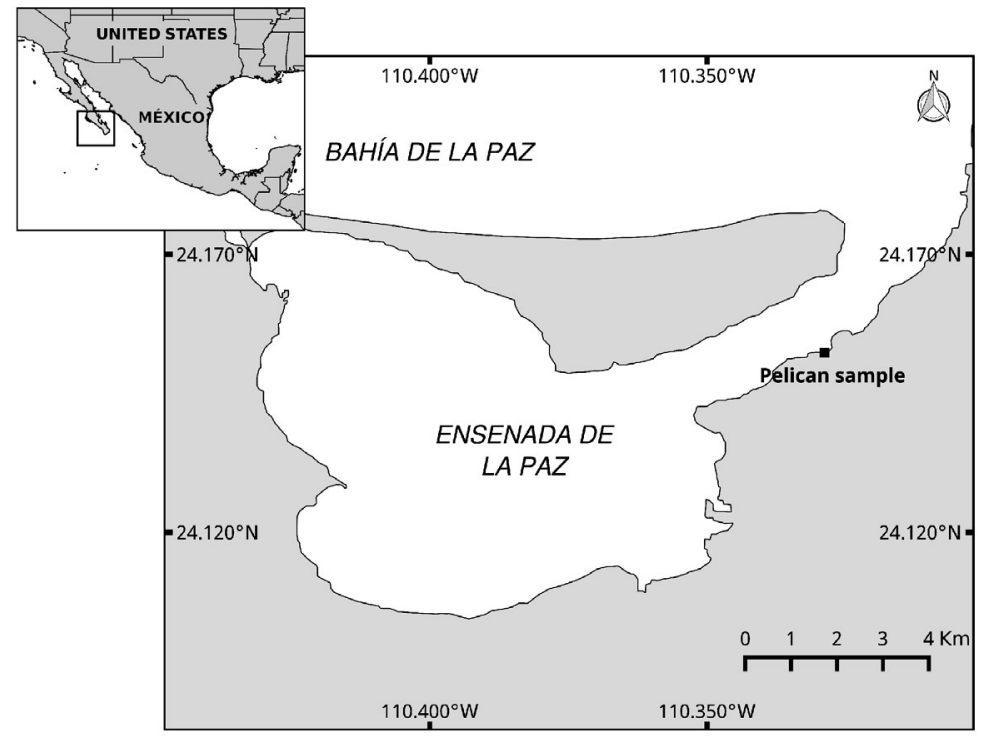

Fig. 1. Geographical zone where mullet Mugil curema were collected and a brown pelican Pelecanus occidentalis was captured ( $\bullet$ ) for this study 
to the Department of Parasitology at the University of Granada (Spain) where they were dissected to extract the eggs. These females were then analysed for molecular identification (see below). The third larval stage (L3) of C. multipapillatum s.l. from mullet Mugil curema captured in the same geographical area were collected for genetic identification.

\section{Molecular identification}

For genetic identification of the L3 larvae of $C$. multipapillatum from mullet and of the adult female C. multipapillatum collected from the brown pelican, PCR of the ribosomal fragment ITS1-5.8S-ITS2 of the nuclear genome was carried out. In brief, the procedure described by Ausubel et al. (2002) was employed to extract the genomic DNA of every parasite. The PCR amplification primers NC5 (forward) and NC2 (reverse) described by Zhu et al. (2000) were employed. The expected size of the amplified fragment was $1000 \mathrm{bp}$. PCR products were run through electrophoresis in $1 \%$ agarose gel and visualized with SYBR Gold dye and a transilluminator. The DNA was purified and sequenced by MacroGen (South Korea).

\section{Analysis of sequences}

In brief, the sequences were edited and aligned with Clustal X (version 2.0). A phenetic analysis was carried out. Trees were constructed using neighbourjoining (NJ) analysis, based on Kimura-2-parameter (K2P) distance (Kimura 1980) values, using MEGA 5.05 (Tamura et al. 2011). The reliabilities of the measure of stability of the branches were evaluated using nonparametric bootstrap analysis (Felsenstein 1985) for the NJ tree, with 1000 bootstrap replicates.

\section{Maintenance and cultivation}

The eggs were taken from the most external part of the uteri, placed in tubes of tap water, centrifuged at $600 \times g$ for $10 \mathrm{~min}$ and the supernatant decanted. Next, $9 \%$ NaCl solution was added, and the tubes were centrifuged at $600 \times g$ for $10 \mathrm{~min}$, after which the eggs were placed in an antibiotic-antimycotic solution for $30 \mathrm{~min}$ for axenization (Iglesias et al. 1997). The eggs were then washed with sterile $9 \%$ $\mathrm{NaCl}$ solution and centrifuged at $600 \times g$. After resuspension in this saline solution, the solution was divided into 3 aliquots which were then centrifuged, decanted and the eggs resuspended in a volume of sterile $\mathrm{NaCl}$ solution at 9, 28 and $35 \%$, respectively. Aliquots of $1 \mathrm{ml}$ with 200 eggs were placed in the wells of sterile polystyrene culture plates, in triplicate, which were incubated separately at 15 and $24^{\circ} \mathrm{C}$. The development of the eggs was monitored to distinguish the different stages, and we recorded hatching and survival of the larvae in the saline solutions, which were renewed weekly. After 1 mo under these conditions, the saline solution in the wells was changed to a solution of Grace's insect medium supplemented with $2 \%$ v/v basal medium Eagle's vitamins $(100 \times)$ solution, $1 \mathrm{mM}$ L-cysteine, $1 \mathrm{~g} \mathrm{l}^{-1}$ glucose, $20 \% \mathrm{v} / \mathrm{v}$ heat-inactivated foetal bovine serum and $1 \% \mathrm{v} / \mathrm{v}$ RPMI-1640 amino acid solution (50x), adjusting $\mathrm{pH}$ to 7.2 , without changing the other experimental conditions and the observation of larval development. The culture medium was renewed weekly. The experiments were deemed to be completed when dead larvae outnumbered live larvae.

\section{RESULTS}

The genetic analyses of the ITS1-5.8S-ITS2 sequences of both adult female Contracaecum collected from the brown pelican and L3 larvae collected from mullet in Bahía de La Paz showed 100\% identity (Table 1; K2P = 0; Fig. 2).

During the first developmental stages (up to the morula), the eggs from the uteri of female C. multipapillatum s.l. placed in different saline solutions measured (mean $\pm \mathrm{SD}$ ) $53.4 \pm 3.4 \times 43.1 \pm 4.1 \mu \mathrm{m}(\mathrm{n}=$ 13). When the larvae developed inside the eggs, these increased in size up to $65.6 \pm 5.4 \times 54.8 \pm 4.5 \mu \mathrm{m}$ ( $\mathrm{n}=12$ ). Optical microscopy observations revealed that the eggs had either 2 layers with a smooth covering or 3 layers with a slightly rough covering (Fig. 3).

The eggs exhibited negative buoyancy in all tested saline solutions, depositing on the bottom of the culture wells. Most of the eggs (>85\%) left to incubate in the different saline solutions developed as far as forming larvae (Fig. 4A,B) which later hatched (Fig. 4A,C) in large numbers (61-98\%). However, the speed of development and the survival of the larvae differed according to incubation conditions. At $15^{\circ} \mathrm{C}$ (Table 2), salinity did not seem to significantly affect the mean hatch percentage (average range $80-97 \%$ ) or the survival of the hatched larvae (75-82\%, mean percentage of larvae alive at the end of the experiment). Furthermore, a notable increase was observed in the slope of the eclosion curve from Day 11 onwards (not 


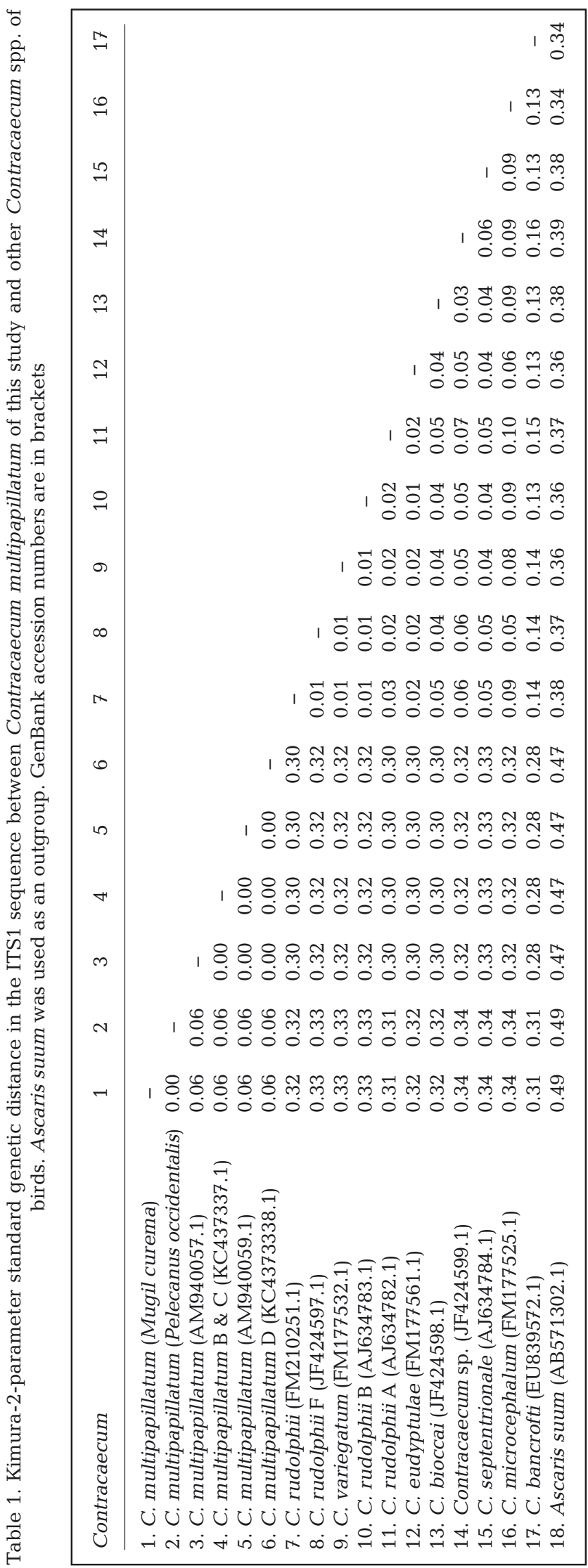

shown). When the same experiment was carried out at $24^{\circ} \mathrm{C}$, the notable increase in the slope of the hatching curve occurred towards Day 13 and did not seem to be affected by the salinity of the medium (not shown). However, the hatch percentage was slightly lower than at $15^{\circ} \mathrm{C}$ (Table 2), while there was a slight increase in mean hatch percentage (71-80\%) with increasing salinity. On the other hand, the mean percentage of larvae alive at the end of the experiment was lower at $24^{\circ} \mathrm{C}(30-55 \%)$ than at $15^{\circ} \mathrm{C}(75-82 \%)$, apparently influenced by the salinity, such that survival decreased as salinity increased (Table 2). In summary, increasing the temperature from 15 to $24^{\circ} \mathrm{C}$ reduced the percentage of hatching and survival of the larvae; the increase in salinity reduced larval survival at $24^{\circ} \mathrm{C}$, with a slight increase in hatching at either temperature.

Recently hatched larvae showed a boring tooth, oesophagus and a developing intestine, which frequently presented 1 or 2 large clear areas in both anterior and posterior zones (Fig. 5A), as well as a striated sheath corresponding to the cuticle of the previous larval stage (Fig. 5). As the larvae developed, the nerve ring, the excretory duct, the ventriculus, the ventricular appendix - with differing degrees of development — and the rectum could also be observed (Fig. 5B). The intestinal caecum could not be observed at this stage, at least not during the period of maintenance.

Live larvae collected from the previous experiment at $24^{\circ} \mathrm{C}$ were placed in wells with $1 \mathrm{ml}$ of Grace's modified medium at the same temperature. These larvae were ensheathed (Fig. 5) and measured 261.0 $\pm 38.1 \times 15.8 \pm 2.9 \mu \mathrm{m}(\mathrm{n}=23)$, or $297.8 \pm 16.3 \mu \mathrm{m}$ $(\mathrm{n}=8)$ including the sheath. The larvae tended to be highly mobile during this stage, exhibiting a flicking motion, but with periods at rest. Some larvae adhered to each other or to fibrous substrates in the culture medium, using the posterior end of the sheath, which finishes in a point (Fig. 5C and see Video S1 in the Supplement at www.int-res.com/ articles/suppl/d125p167_supp/). After $14 \mathrm{~d}$ under these conditions, the larvae had grown sufficiently to fill the sheath while some started to free themselves upon reaching a length of around $315 \mu \mathrm{m}(314.4 \pm$ $51.1 \times 18.5 \pm 2.0 \mu \mathrm{m}, \mathrm{n}=7$ ). The larvae freed themselves from the sheath at different times using rapid movements. However, some failed to achieve this under our experimental conditions (Fig. 6A). Over the $25 \mathrm{~d}$ of experiments, $\sim 2 \%$ of the larvae exsheathed, growing more than $70 \mu \mathrm{m}(333.4 \pm 39.2 \times$ $21.9 \pm 5.8 \mu \mathrm{m}, \mathrm{n}=3$ ) with no new moulting observed. The freed larvae exhibited a more serpentine and 
Fig. 2. Neighbour-joining reconstruction between sequences of Contracaecum multipapillatum obtained in this study (in bold, also showing the host) and sequences of Contracaecum species collected from birds, obtained from the NCBI database, with the tree inferred from the ITS1 data set. The numbers on the tree branches represent the percentage of bootstrap resampling (with 1000 replicates). Ascaris suum was used as an outgroup. GenBank accession num-

bers are in front of species names

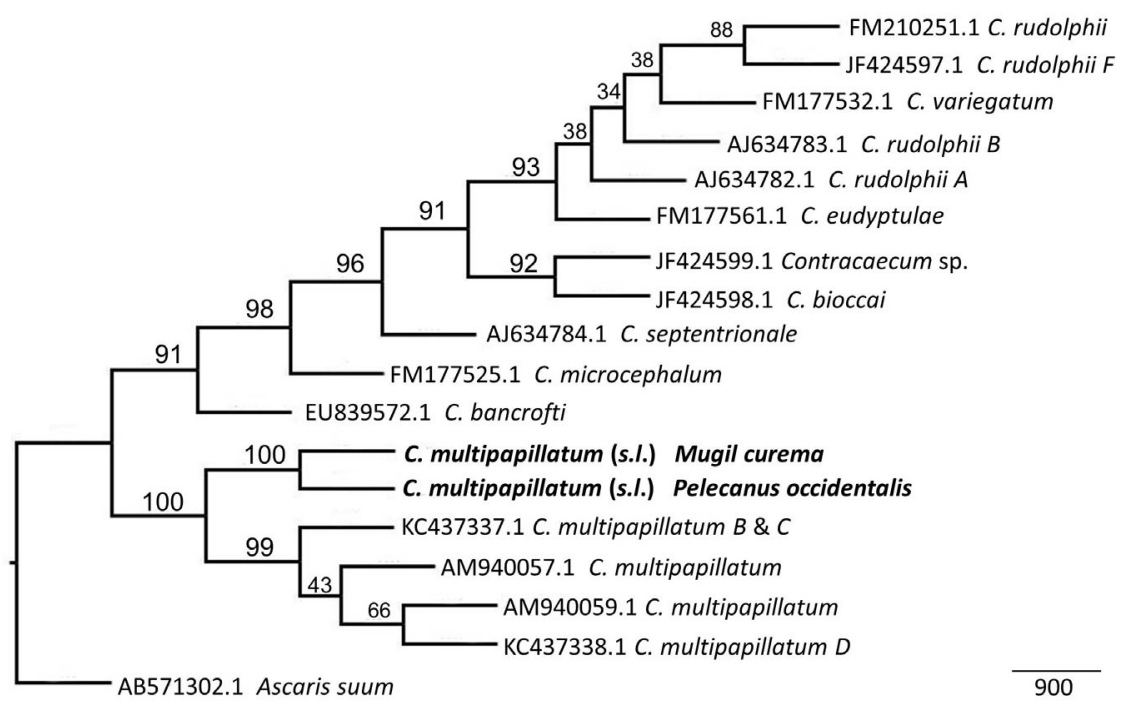

less vigorous type of movement than that of the ensheathed larvae and tended not to adhere as much to the substrates of the medium using the posterior end. At the end of the experiment, more than $50 \%$ of the larvae were dead. When culture was carried out at $15^{\circ} \mathrm{C}$, a similar pattern was observed, although exsheathment did not occur within the timespan of the experiment but was observed later. Exsheathed larvae observed by optical microscopy also revealed an oesophagus, ventriculus, ventricular appendix, incipient intestinal cecum, intestine, rectum and the excretory cell, excretory duct and excretory pore (Fig. 6). From when the larvae began to exsheathe the intestinal contents were seen to actively move,

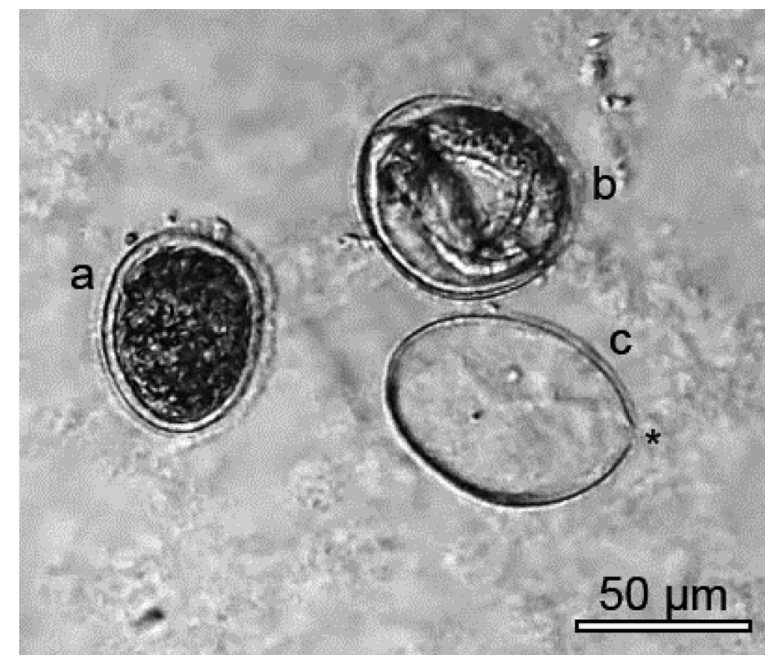

Fig. 3. Eggs of Contracaecum multipapillatum s.l. under an optical microscope. Egg 'a' has 3 layers, with the outer layer slightly rough. Egg 'b' has 2 smooth layers and contains larvae, and egg ' $c$ ' is empty after hatching of the larvae, with the exit hole visible $(*)$ alternating between the ventriculus and the rectum (see Video S2).

\section{DISCUSSION}

The nematodes collected from the brown pelican and mullet were identified as belonging to the complex of species of Contracaecum multipapillatum s.l. (K2P < 0.07), clearly separated from other species and complexes of Contracaecum that infect birds (K2P > 0.30; Table 1, Fig. 2), as shown by phenetic analysis.

Most of the eggs collected from the uteri of C. multipapillatum s.l. females obtained from the brown pelican were already embryonated, probably as a result of the time elapsed between the collection of the nematodes and the removal of the eggs. Huizinga (1967) reported that the eggs collected from the uteri of females were either not embryonated or were in a 2- or 4-cell state. Various authors have described a certain degree of embryonation (up to the morula stage) in both anisakid eggs taken from the uterus and those passed in faeces of the host (Thomas 1937, Grabda 1976, Brattey 1990). However, Adroher et al. (2004) reported that the eggs spontaneously liberated in culture by females of Hysterothylacium aduncum, a gastrointestinal anisakid of fish, were not embryonated. The eggs collected in the present study measured approximately $53 \times 43 \mu \mathrm{m}$. VidalMartínez et al. (1994) reported eggs measuring $53 \times$ $38 \mu \mathrm{m}$, Huizinga (1967) reported $65 \times 58 \mu \mathrm{m}$, and Lucker (1941) reported ca. $60 \times 50 \mu \mathrm{m}$. Although the last 2 measurements are greater than those found in the present study, they are similar to those for the 


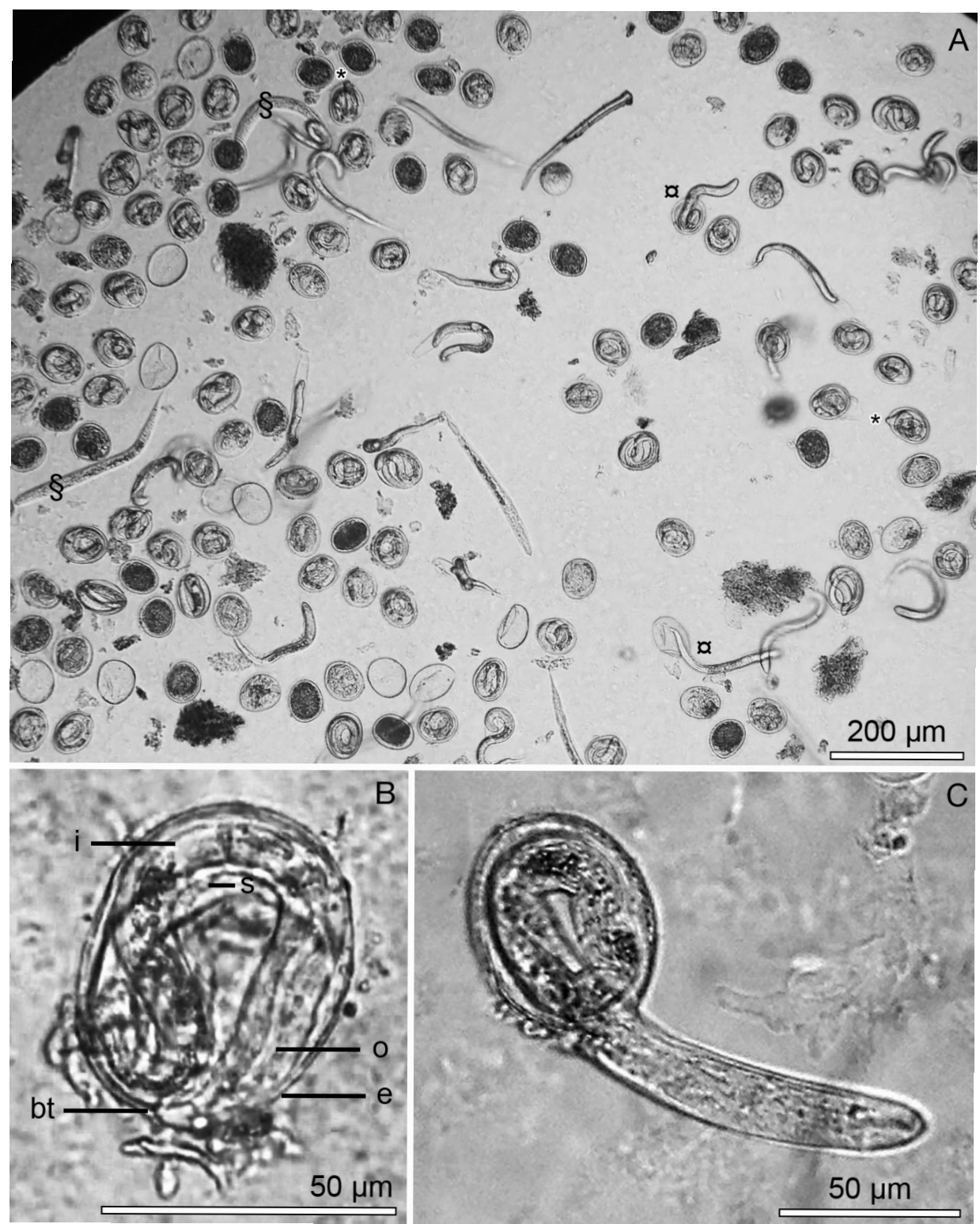

Fig. 4. Eggs and larvae of Contracaecum multipapillatum s.l. during development. (A) Larvae within eggs, with larvae pushing the eggshell to hatch (*), larvae hatching (đ), empty eggs, larvae with sheath and some exsheathed larvae (§); note that these are larger than ensheathed larvae. (B) Larva in an egg, with the boring tooth (bt), oesophagus (o), intestine (i) and sheath (s) visible. (C) Larva during hatching
Table 2. Effect of salinity and temperature on development and hatching of eggs and survival of hatched larvae of Contracaecum multipapillatum s.l. Data are mean (range) for eggs from 2 different females, except where marked. Experiments were performed in triplicate

\begin{tabular}{|lcccc}
\hline $\begin{array}{l}\text { Temp } \\
\left({ }^{\circ} \mathrm{C}\right)\end{array}$ & $\begin{array}{c}\mathrm{NaCl} \\
(\%)\end{array}$ & $\begin{array}{c}\text { Unhatched } \\
\text { eggs }(\%)\end{array}$ & $\begin{array}{c}\text { Hatched } \\
\text { eggs }(\%)\end{array}$ & $\begin{array}{c}\text { Larvae } \\
\text { alive }(\%)\end{array}$ \\
\hline 15 & $9^{\mathrm{a}}$ & 12 & 88 & 75 \\
& 28 & $19(12-27)$ & $80(73-88)$ & $82(74-90)$ \\
& 35 & $3(2-5)$ & $97(95-98)$ & $81(79-82)$ \\
24 & 9 & $29(19-39)$ & $71(61-81)$ & $55(48-62)$ \\
& 28 & $25(22-28)$ & $75(72-78)$ & $40(36-44)$ \\
& 35 & $20(18-21)$ & $80(79-82)$ & $30(12-47)$
\end{tabular}

${ }^{\mathrm{a}}$ Eggs from a single female eggs with the developed larvae inside, which measured up to $66 \times 55 \mu \mathrm{m}$, probably due to the lack of rigidity and elasticity of the egg shell associated with the movement of the larva inside the egg, as suggested by Adroher et al. (2004). The eggs exhibited negative buoyancy in all solutions, as in other anisakids (Huizinga 1966, Adroher et al. 2004). This could explain why mullet, which are catadromous fish, are usually infected with Contracaecum in endemic zones, since they feed on detritus, micro-algae and benthic organisms in sandy- or muddy-bottomed coastal areas where the eggs and larvae of these parasites can be found, either free or within copepod hosts (Salgado-Maldonado \& Barquín-Álvarez 1978, Deardorff \& Overstreet 1980, Chávez López \& 

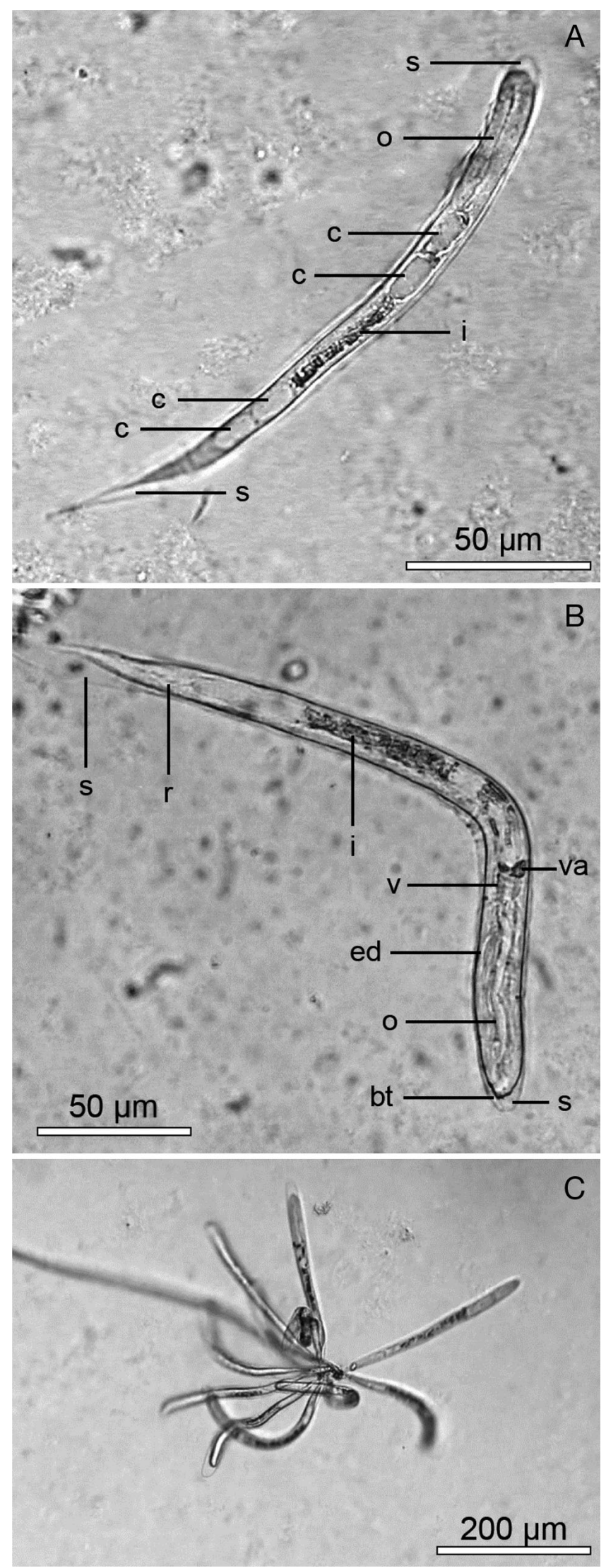

Montoya Mendoza 1988, Juárez-Arroyo \& SalgadoMaldonado 1989).

According to Huizinga (1967), the shell of the eggs of C. multipapillatum is thin with 2 layers: a transparent, adhesive and lightly mamillated outer layer and a thin inner vitelline layer. Although some eggs in the present study had 2 apparently smooth layers, many seemed to have 3 layers, the outermost layer being slightly rough (Fig. 3). Among anisakid eggs, a double covering, with a smooth or slightly undulating outer layer is frequently present (see Anderson 2000 for references); however, a triple covering with a rough outer layer has been reported in another anisakid (Adroher et al. 2004).

Many authors, working with different anisakids, have shown that the development of the eggs is directly related to the maintenance temperature, such that they develop more rapidly with increasing temperature, with a maximum around $13-20^{\circ} \mathrm{C}$. Temperature has also been shown to affect the infectivity of the larvae for the first host, at least in the anisakid Pseudoterranova decipiens (see Palm 1999 for references). The salinity of the medium has also been shown to have an effect in Anisakis simplex, with increasing numbers of eggs hatched when salinity was $10 \%$ or greater (Højgaard 1998). In the present study, hatching of C. multipapillatum s.l. was greatest at $15^{\circ} \mathrm{C}$, tending to increase slightly with salinity, both at $15^{\circ} \mathrm{C}$ and at $24^{\circ} \mathrm{C}$ (Table 2). The fact that we found only slight differences with temperature could be due to working within a range of high temperatures $\left(15-24^{\circ} \mathrm{C}\right)$. The hatching percentages reported for different species of anisakids vary greatly, not only due to experimental conditions but also to the species and strains employed (see Bier 1976 for references). Hatching was high in the present study (61-98\%).

The decrease in the percentage of live larvae at the end of the experiment at $24^{\circ} \mathrm{C}$ compared to at $15^{\circ} \mathrm{C}$ and its relationship with salinity at $24^{\circ} \mathrm{C}$ may be due to a more rapid development/metabolism of the larvae as a result of the higher incubation temperature and the efforts of the larvae to maintain osmotic equilibrium. Both would require greater

Fig. 5. Ensheathed larvae of Contracaecum multipapillatum s.l. (A) Newly hatched larva with developing intestine containing large clear areas at both ends. (B) Hatched larva that is older than the larva in (A), showing more advanced development. (C) Larvae in a cluster attached to the substrate and to each other by the posterior end of their sheaths. bt: boring tooth; c: clear areas; ed: excretory duct; i: intestine; o: oesophagus; r: rectum; s: sheath; v: ventriculus; va: incipient ventricular appendix 

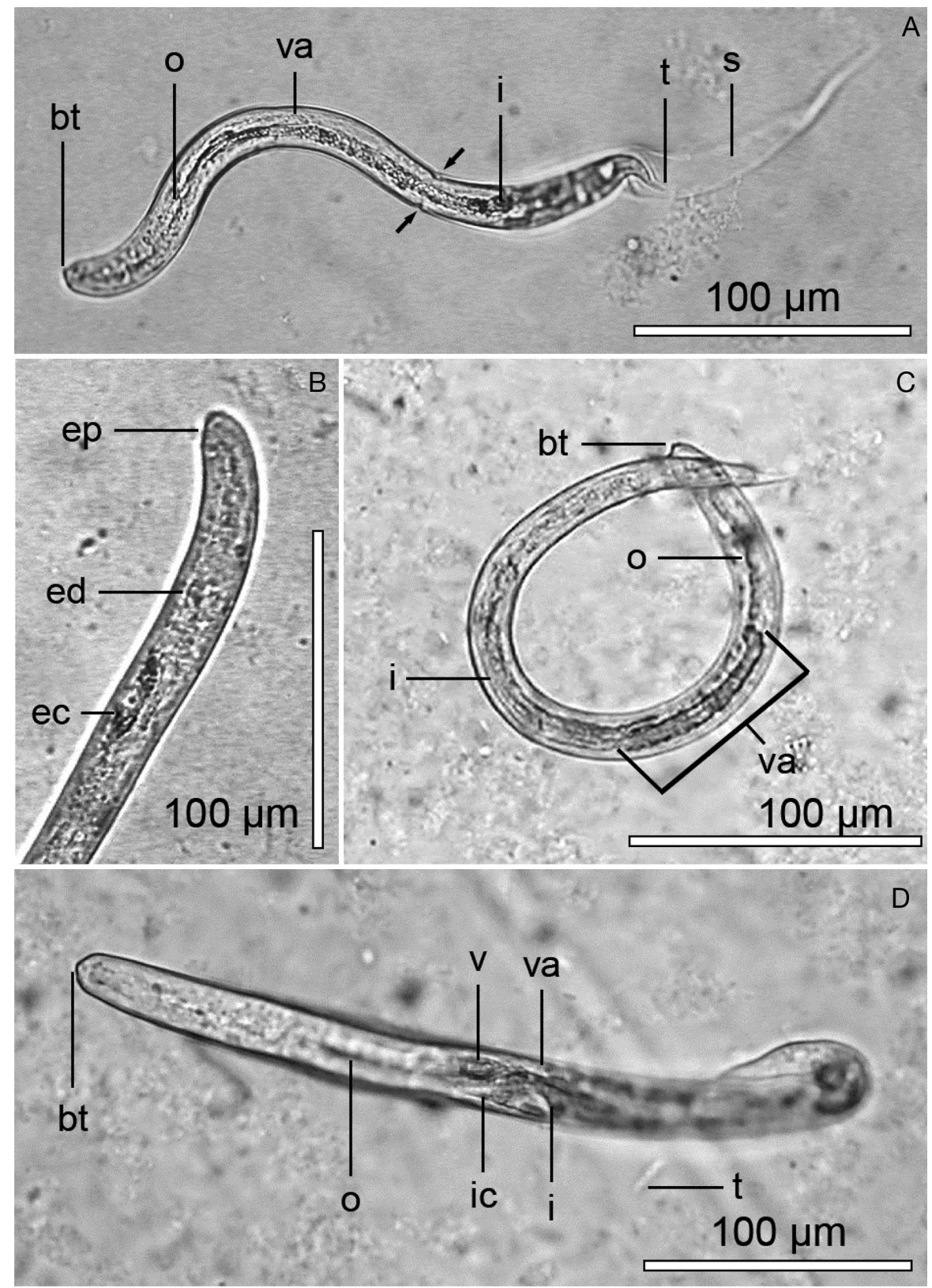

Fig. 6. (A) Exsheathing larva and (B-D) exsheathed larvae of Contracaecum multipapillatum s.l. bt: boring tooth; ec: excretory cell; ed: excretory duct; ep: excretory pore; i: intestine; ic: incipient intestinal caecum; o: oesophagus; s: sheath; t: tail; v: ventriculus; va: ventricular appendix. The arrows in panel (A) indicate the strangulation caused by the sheath during larval exsheathment

energy expenditure by the larvae, still ensheathed, resulting in their exhausting their energy reserves within the saline medium, which lacks exogenous energy substrates. Similar results were obtained for C. rudolphii s.l. collected from cormorants (Dziekońska-Rynko \& Rokicki 2010). The high rate of hatching and survival of the larvae in all of the saline solutions used in our study (Table 2), particularly at $15^{\circ} \mathrm{C}$, suggests that the life cycle of this parasite can take place both in the sea and in fresh or brackish water. This has also been suggested for other anisakids such as C. osculatum baicalensis, $H$. aduncum and P. decipiens (Sudarikov \& Ryzhikov 1951, Yoshinaga et al. 1987, Burt et al. 1990). The presence or absence of light during culture at $24^{\circ} \mathrm{C}$ had no significant effect on the results (not shown). 
Much debate surrounds the larval stage which hatches from anisakid eggs. Køie (1993), Køie \& Fagerholm (1993) and Køie et al. (1995) found that a larva is enclosed by 2 cuticles before hatching and is consequently third-stage, at least in H. aduncum, C. osculatum, A. simplex and $P$. decipiens. Smith et al. (1990) successfully infected trout intraperitoneally with larvae of $C$. osculatum which had recently been hatched ( 0.4 $\mathrm{mm}$ in length), and they studied the development of the larvae up to $13 \mathrm{~mm}$ and with L3 characteristics, without observing any moulting. Thomas (1937) had already shown that it was the L3 that emerged from the egg of C. spiculigerum (=C. rudolphii) after 2 moults inside it. Similar results were reported by Moravec (2009). In this respect, in the other anisakids mentioned it has not been possible so far to demonstrate the existence of new moults after hatching and before reaching the final host, suggesting that, at least in most anisakids, the L3 hatches from the egg. However, other authors believe that it is the L2 that hatches from the egg (Huizinga 1966, 1967, Measures \& Hong 1995, Bartlett 1996).

To our knowledge, our study is the first to attempt the laboratory culture of hatched C. multipapillatum larvae in a nutritive medium. If the proposal of Huizinga (1967) is correct, then the larvae obtained from hatching the eggs of $C$. multipapillatum s.l. must be L2, despite the belief of many authors that the larvae hatching from the eggs of the anisakids studied are L3 (see above). The size of the recently hatched larvae $(261 \times 16 \mu \mathrm{m})$ is smaller than the $362 \times 13 \mu \mathrm{m}$ reported by Huizinga (1967). These larvae exhibited a flicking motion, which has also been described in other species of anisakids (Davey 1969, McClelland \& Ronald 1974a, Adroher et al. 2004), and they were often attached to each other by the posterior end of their sheaths, forming clusters, or to eggshells or to substrates in the medium (Video S1), in a similar way to that described for hatched larvae of C. spiculigerum (=C. rudolphii), $P$. decipiens or $A$. simplex (Thomas 1937, Huizinga 1966, McClelland \& Ronald 1974b, Højgaard 1998). The culture medium, at $24^{\circ} \mathrm{C}$, permitted some growth in the larvae, leading to exsheathment and a subsequent increase in diameter up to $22 \mu \mathrm{m}$ as well as a change to a slower, less vigorous serpentine swimming movement. This change has been observed in other anisakids such as H. aduncum (R. Benítez \& F. J. Adroher unpublished) and C. osculatum (Davey 1969). As other authors have also shown, an increase in temperature results in more rapid development of the eggs and larvae (McClelland 1990, Measures 1996). This would ex- plain the exsheathment in the medium at $24^{\circ} \mathrm{C}$, but not at $15^{\circ} \mathrm{C}$, in the $25 \mathrm{~d}$ of the experiment, although, at the latter temperature, this was observed some days after completing data collection. However, in no case were additional moults observed.

According to Huizinga (1967), exsheathment takes place in the intestine of the copepod, the first host of the parasite, as has also been observed in C. osculatum (Davey 1969). The larvae grow within the sheath, often filling it completely, before freeing themselves of it. We observed larvae in the process of exsheathing in which the pressure exerted by the sheath on the body of the larva at the point of exit can be seen to be strangling it (Fig. 6A). In fact, in the cultures some larvae were seen to be unable to exsheathe completely. Although it is not known whether digestive enzymes of the copepod are needed to facilitate or stimulate exsheathment, proteases have been shown to be involved in hatching, exsheathment and moulting in nematodes (reviewed by Malagón et al. 2013). Finally, the description of recently exsheathed larvae (Fig. 6) is very similar to that of L3 found in the fish hosts of C. multipapillatum s.l., although less developed and smaller. This suggests that it could be the L3 larval stage that hatches from the egg in this nematode, as occurs in other anisakids (see above). These larvae appear to have a functional intestine, since, on exsheathing, intense movement of the intestinal content was observed (Video S2). This was probably a result of entering into direct contact with the medium on escaping from the sheath, although it is not known whether the larvae at this stage were able to ingest food.

The high prevalence of infection by Contracaecum spp. in mullet (95\% in Mugil curema and $100 \%$ in $M$. cephalus) and pelicans (83\% in Pelecanus occidentalis) in the area of La Paz, Mexico (Iglesias et al. 1998, Valles-Vega 2011, 2014), which probably maintains the life cycle of $C$. multipapillatum s.l. in this geographical zone (Fig. 7), could be explained by the following: the density of the eggs of C. multipapillatum s.l., which is greater than that of seawater, their ability to develop and the survival of the larvae at both temperate $\left(15^{\circ} \mathrm{C}\right)$ and high temperatures $\left(24^{\circ} \mathrm{C}\right)$ and at different salinities $(9,28$ and $35 \%$ ), and, finally, on the one hand, the catadramous behaviour and benthic feeding habits of the mullet, and, on the other hand, the frequent consumption of these fish by pelicans (Humphrey et al. 1978). Cannon (1977) noted that Contracaecum and Thynnascaris (=Hysterothylacium) occur principally in bottom feeders.

Regarding the possible first crustacean host of the parasite in this zone, Valles-Vega (2014) made sev- 


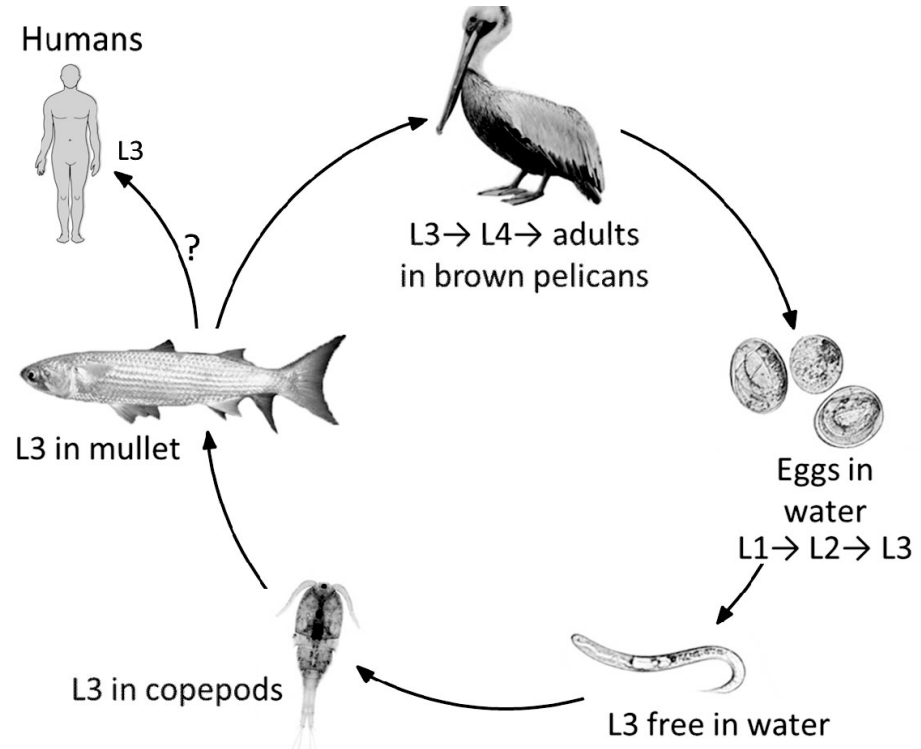

Fig. 7. Tentative life cycle of Contracaecum multipapillatum s.l. in the geographical area of Bahía de La Paz, Gulf of California, Mexico

eral unsuccessful attempts to experimentally infect omnivorous marine copepods such as Acartia clausi, A. lilljeborgi and Centropages furcatus from Bahía de La Paz or Calanus helgolandicus, Centropages typicus and Acartia sp. from Motril waters (northern Alborán Sea in the western Mediterranean Sea), with recently hatched larvae. However, Huizinga (1967) was able to experimentally infect the freshwater copepod Cyclops vernalis.

Previous studies in Bahía de La Paz showed that surface water temperature varies during the annual cycle from a minimum average of $20.5^{\circ} \mathrm{C}$ in winter to an average maximum of $31^{\circ} \mathrm{C}$ in summer, not significantly varying until $100 \mathrm{~m}$ depth (Obeso-Nieblas et al. 2008, Guevara-Guillén et al. 2015). Salinity shows minimal annual changes depending on river inputs and evaporation, ranging between averages of 34.5\% in winter and 39\% in summer (Chávez-Sánchez 2012). Finally, in the study area, Palomares-García (1996) showed that the copepods, intermediate hosts of Contracaecum, occur throughout the year, and their abundance is related to the seasonal hydrographic changes, with up to 129 species of copepods documented (Aceves-Medina et al. 2007 for references), the most abundant being A. clausi, A. lilljeborgi and $C$. furcatus (S. Hernández-Trujillo unpublished data). There are also mullet (intermediate/ paratenic hosts) and pelicans (final hosts) throughout the year (I. Valles-Vega unpublished data). These data show that the life cycle of C. multipapilatum s.l. is likely to occur throughout the year in this area of the Gulf of California, since, as we have shown, $C$. multipapilatum L3 from the mullet and C. multipapilatum adults from the brown pelican correspond to the same species $(\mathrm{K} 2 \mathrm{P}=0)$.

Acknowledgements. This work was funded by the Spanish grant CGL2013-47725-P from the Ministerio de Economía y Competitividad and European Regional Development Fund (ERDF) and Mexican grant SIP20141443 from IPN. We are grateful to Dr. María del Carmen Gómez del Prado Rosas and Dr. David Malagón for advice and collaboration and Dr. Bárbara González Acosta (from the Microbiology lab of CICIMAR, La Paz, Mexico) for help with the genetic identification of the parasites. Translation to English was by Robert Abrahams, BSc.

\section{LITERATURE CITED}

Aceves-Medina G, Esqueda-Escárcega GM, PachecoChávez R, Zárate-Villafranco A, Hernández-Alonso JR, Hernández-Trujillo S (2007) Cambios diarios en la composición y abundancia de copépodos planctónicos al sur de Bahía de La Paz (Octubre 2002). Hidrobiologica 17: 185-188

Adroher FJ, Malagón D, Valero A, Benítez R (2004) In vitro development of the fish parasite Hysterothylacium aduncum from the third larval stage recovered from a host to the third larval stage hatched from the egg. Dis Aquat Org 58:41-45

Anderson RC (2000) Nematode parasites of vertebrates. Their development and transmission, $2^{\text {nd }}$ edn. CABI Publishing, Wallingford

Ausubel FM, Brent R, Kingston RE, Moore DD and others (2002) Short protocols in molecular biology: a compendium of methods from current protocols in molecular biology. John Wiley \& Sons, New York, NY

Barros LA, Tortelly R, Pinto RM, Gomes DC (2004) Effects of experimental infections with larvae of Eustrongylides ignotus Jäegerskiold, 1909 and Contracaecum multipapillatum (Drasche, 1882) Baylis, 1920 in rabbits. Arq Bras Med Vet Zootec 56:325-332

* Bartlett CM (1996) Morphogenesis of Contracaecum rudolphii (Nematoda: Ascaridoidea), a parasite of fish-eating birds, in its copepod precursor and fish intermediate hosts. Parasite 3:367-376

*Bier JW (1976) Experimental anisakiasis: cultivation and temperature tolerance determinations. J Milk Food Technol 39:132-137

Brattey J (1990) Effect of temperature on egg hatching in three ascaridoid nematode species from seals. Can Bull Fish Aquat Sci 222:27-39

Burt MDB, Smith JW, Jarecka A, Pike AW, Wootten R, McClelland G (1990) Pseudoterranova decipiens (Nematoda: Ascaridoidea): time of development to hatching of larvae at different temperatures and salinities. Can Bull Fish Aquat Sci 222:41-45

Cannon LRG (1977) Some ecological relationships of larval ascaridoids from south-eastern Queensland marine fishes. Int J Parasitol 7:227-232

Chávez López R, Montoya Mendoza J (1988) Nematodos y acantocéfalos del tracto digestivo de la lebrancha Mugil 
curema (Valenciennes, 1836) de la laguna de Tamihaua, Veracruz. BSc thesis, UNAM, Mexico City

Chávez Sánchez T (2012) Composición y abundancia de especies de florecimientos macroalgales y su relación con variables ambientales en la Ensenada de La Paz, Baja California Sur. MSc thesis, Centro de Investigaciones Biológicas del Noroeste, La Paz

* Daschner Á, Cuéllar C, Rodero M (2012) The Anisakis allergy debate: Does an evolutionary approach help? Trends Parasitol 28:9-15

Davey JT (1969) The early development of Contracaecum osculatum. J Helminthol 43:293-298

Weardorff TL, Overstreet RM (1980) Contracaecum multipapillatum (synonym $=C$. robustum) from fishes and birds in the northern Gulf of Mexico. J Parasitol 66: 853-856

* Dziekońska-Rynko J, Rokicki J (2010) Effect of temperature, $\mathrm{NaCl}$ concentration and aeration of solutions on the survivability of II stage larvae of Contracaecum rudolphii Hartwich, 1964. Wiad Parazytol 56:43-49

Felsenstein J (1985) Confidence limits on phylogenies: an approach using the bootstrap. Evolution 39:783-791

Grabda J (1976) Studies on the life cycle and morphogenesis of Anisakis simplex (Rudolphi, 1809) (Nematoda: Anisakidae) cultured in vitro. Acta Ichthyol Piscat 6: 119-141

* Guevara-Guillén C, Shirasago-Germán B, Pérez-Lezama EL (2015) The influence of large-scale phenomena on La Paz Bay hydrographic variability. Open J Mar Sci 5: 146-157

Højgaard DP (1998) Impact of temperature, salinity and light on hatching of eggs of Anisakis simplex (Nematoda, Anisakidae), isolated by a new method, and some remarks on survival of larvae. Sarsia 83:21-28

Huizinga HW (1966) Studies on the life cycle and development of Contracaecum spiculigerum (Rudolphi, 1809) (Ascaridoidea: Heterocheilidae) from marine piscivorous birds. J Elisha Mitchell Sci Soc 82:180-195

Huizinga HW (1967) The life cycle of Contracaecum multipapillatum (von Drasche, 1882) Lucker, 1941 (Nematoda: Heterochelidae). J Parasitol 53:368-375

Humphrey SR, Courtney CH, Forrester DJ (1978) Community ecology of the helminth parasites of the brown pelican. Wilson Bull 90:587-598

Iglesias L, Valero A, Adroher FJ (1997) Some factors which influence the in vitro maintenance of Anisakis simplex (Nematoda). Folia Parasitol 44:297-301

Iglesias L, Gómez del Prado MC, Adroher FJ, Valero A (1998) Floridosentis elongatus y Contracaecum sp., parásitos de Mugil cephalus en Baja California Sur, México. First Virtual Congress about Pharmacy (IVCP), Universidad de Granada, free contribution no. C-068

Iglesias L, Benítez R, Adroher FJ, Valero A (2011) Helminth infection in Mugil incilis from Cartagena de Indias, Colombian Caribbean coast. Helminthologia 48:36-40

Im KI, Shin HJ, Kim BH, Moon SI (1995) Gastric anisakiasis cases in Cheju-do, Korea. Korean J Parasitol 33:179-186

Ishikura H, Takahashi S, Sato N, Matsuura A, Nitto H, Tsunokawa M, Kikuchi K (1996) Epidemiology of anisakidosis and related human diseases and studies on parasites infecting marine mammals, fishes and squids. Bull Mar Biomed Inst Sapporo Med Univ Sch Med 3: 23-37

Juárez-Arroyo J, Salgado-Maldonado G (1989) Helmintos de la 'lisa' Mugil cephalus Lin. en Topolobambo, Sinaloa,
México. An Inst Biol Univ Nac Auton Mex Ser Zool 60: 279-295

Kimura M (1980) A simple method for estimating evolutionary rate of base substitution through comparative studies of nucleotide sequences. J Mol Evol 16:111-120

Køie M (1993) Aspects of the morphology and life cycle of Hysterothylacium aduncum (Rudolphi, 1802) (Nematoda, Ascaridoidea, Anisakidae). Can J Zool 71:1289-1296

Køie M, Fagerholm HP (1993) Third-stage larvae emerge from eggs of Contracaecum osculatum (Nematoda, Anisakidae). J Parasitol 79:777-780

Køie M, Berland B, Burt MDB (1995) Development to thirdstage larva occurs in eggs of Anisakis simplex and Pseudoterranova decipiens (Nematoda, Ascaridoidea, Anisakidae). Can J Fish Aquat Sci 52:134-139

Lucker JT (1941) A redescription of Contracaecum multipapillatum (von Drasche, 1882). J Parasitol 27:505-512

Malagón D, Benítez R, Kašný M, Adroher FJ (2013) Peptidases in parasitic nematodes - a review. In: Eizinger GS (ed) Parasites: ecology, diseases and management. Nova Sciences Publishers, Hauppauge, NY, p 61-102

* Mattiucci S, Paoletti M, Solórzano AC, Nascetti G (2010) Contracaecum gibsoni n. sp. and C. overstreeti n. sp. (Nematoda: Anisakidae) from the Dalmatian pelican Pelecanus crispus (L.) in Greek waters: genetic and morphological evidence. Syst Parasitol 75:207-224

McClelland G (1990) Larval sealworm (Pseudoterranova decipiens) infections in benthic macrofauna. Can Bull Fish Aquat Sci 222:47-65

* McClelland G, Ronald K (1974a) In vitro development of the nematode Contracaecum osculatum Rudolphi 1802 (Nematoda: Anisakinae). Can J Zool 52:847-855

*McClelland G, Ronald K (1974b) In vitro development of Terranova decipiens (Nematoda) (Krabbe, 1878). Can J Zool 52:471-479

Measures LN (1996) Effect of temperature and salinity on development and survival of eggs and free-living larvae of sealworm (Pseudoterranova decipiens). Can J Fish Aquat Sci 53:2804-2807

* Measures LN, Hong H (1995) The number of moults in the egg of sealworm, Pseudoterranova decipiens (Nematoda: Ascaridoidea): an ultrastructural study. Can J Fish Aquat Sci 52:156-160

Moravec F (2009) Experimental studies on the development of Contracaecum rudolphii (Nematoda: Anisakidae) in copepod and fish paratenic hosts. Folia Parasitol 56: 185-193

Obeso-Nieblas M, Shirasago-Germán B, Gaviño-Rodríguez J, Perez-Lezama E, Obeso-Huerta H, Jiménez-Illescas Á (2008) Variabilidad hidrográfica en Bahía de La Paz, Golfo de California, México (1995-2005). Rev Biol Mar Oceanogr 43:559-567

*Palm HW (1999) Ecology of Pseudoterranova decipiens (Krabbe, 1878) (Nematoda: Anisakidae) from Antarctic waters. Parasitol Res 85:638-646

Palomares-García JR (1996) Estructura espacial y variación estacional de los copépodos en la Ensenada de La Paz. Oceánides 11:29-43

Salgado-Maldonado G, Barquín-Álvarez NP (1978) Floridosentis elongatus Ward, 1953 y Contracaecum sp. parásitos de Mugil cephalus Linnaeus, 1758. An Inst Biol Univ Nac Auton Mex Ser Zool 49:71-82

Schaum E, Müller W (1967) Die Heterocheilidiasis. Eine Infektion des Menschen mit Larven von Fisch-Ascariden. Dtsch Med Wochenschr 92:2230-2233 
Shamsi S, Butcher AR (2011) First report of human anisakidosis in Australia. Med J Aust 194:199-200

Smith JW, Elarifi AE, Wootten R, Pike AW, Burt MDB (1990) Experimental infection of rainbow trout, Oncorhynchus mykiss, with Contracaecum osculatum (Rudolphi, 1802) and Pseudoterranova decipiens (Krabbe, 1878) (Nematoda: Ascaridoidea). Can J Fish Aquat Sci 47:2293-2296

Sudarikov VE, Ryzhikov KM (1951) [K biologii Contracaecum osculatum baicalensis-nematody bajkalskoi nerpy]. The biology of Contracaecum osculatum baicalensis - a nematode of the Baikal seal. Tr Gel'mintol Lab Akad Nauk SSSR 5:59-66 (in Russian, with English Abstract)

Tamura K, Peterson D, Peterson N, Stecher G, Nei M, Kumar S (2011) MEGA5: molecular evolutionary genetics analysis using maximum likelihood, evolutionary distance, and maximum parsimony methods. Mol Biol Evol 28: 2731-2739

Thomas LJ (1937) On the life cycle of Contracaecum spiculigerum (Rud.). J Parasitol 23:429-431

*Valero A, Terrados S, Díaz V, Reguera V, Lozano J (2003) Determination of IgE in the serum of patients with allergic reactions to four species of fish-parasite anisakids. J Investig Allergol Clin Immunol 13:94-98

V Valles-Ríos ME，Ruiz-Campos G，Galavíz-Silva L (2000) Prevalencia e intensidad parasitaria en Mugil cephalus (Pisces: Mugilidae), del Río Colorado, Baja California, México. Rev Biol Trop 48:495-501

Editorial responsibility: Bernd Sures, Essen, Germany
Valles-Vega GI (2011) Supervivencia de larvas III de Contracaecum multipapillatum sensu lato (Nematoda: Anisakidae) de lisas (Pisces: Mugilidae) en diferentes medios culinarios y aspectos sobre su ciclo de vida en La Paz, B.C.S. BSc thesis, Universidad Autónoma de Baja California Sur, La Paz

Valles-Vega GI (2014) Estudio experimental de la infección de Contracaecum multipapillatum (Drasche, 1882) (sensu lato) (Nematoda: Anisakidae) en copépodos calanoides. MSc thesis, Instituto Politécnico Nacional-CICIMAR, La Paz

*Vidal-Martínez VM, Osorio-Sarabia D, Overstreet RM (1994) Experimental infection of Contracaecum multipapillatum (Nematoda: Anisakinae) from Mexico in the domestic cat. J Parasitol 80:576-579

Yamaguti S (1961) Systema helminthum, Vol III. The Nematodes of vertebrates, Part I. Interscience Publishers, New York, NY

*Yoshinaga T, Ogawa K, Wakabayashi H (1987) Experimental life cycle of Hysterothylacium aduncum (Nematoda: Anisakidae) in fresh water. Fish Pathol 22: 243-251

* Zhu XQ, D'Amelio S, Paggi L, Gasser RB (2000) Assessing sequence variation in the internal transcribed spacers of ribosomal DNA within and among members of the Contracaecum osculatum complex (Nematoda: Ascaridoidea: Anisakidae). Parasitol Res 86:677-683

Submitted: July 21, 2016; Accepted: June 6, 2017

Proofs received from author(s): July 19, 2017 